\title{
The Language Question and the Paradoxes of Latin Journalism in Eighteenth-Century Hungary
}

\author{
Piroska Balogh
}

It has often been argued that the early modern period was one of the 'emergence', the 'rise' or the 'triumph' of the national vernaculars, at the expense of cosmopolitan Latin on the one hand and local dialects on the other. To the extent that this happened, the phenomenon was important for the creation of new 'speech communities' and eventually new trans-regional or super-regional loyalties. By 1750, the European linguistic system was very different from the medieval system, which had been divided between a living but non-classical Latin and regional dialects which were spoken rather than written. However, the simple statement that the vernaculars of Europe 'rose' is rather a crude one. ${ }^{1}$

This statement by Peter Burke can be found in his 2004 volume Languages and Communities in Early Modern Europe. According to Burke, more comprehensive and differentiated models should be applied in cultural historical research concerning language usage and the awareness of social identity in the seventeenth and eighteenth centuries. He attempts to outline such a model with respect to, among other things, the cultural and sociological status of the Latin language in Europe. According to Burke, in eighteenth-century Europe Latin was not "a language without a speech community," but "a language in search of community." Potential users of the Latin language - that is, its eighteenthcentury target communities - were predominantly "the Catholic Church and the Republic of Letters," meaning Catholic clergymen, scholars, professors and their students, as well as "lawyers, officials, diplomats and travellers." As the primary reason, Burke suggests that Latin appeared useful for creating a virtual international community identity for these linguistic and social communities: "Post-classical Latin, like the vernaculars, exemplifies the uses

1 P. Burke, Languages and Communities in Early Modern Europe (Cambridge 2002), 61. The research project behind this study was supported by the János Bolyai Research Fellowship of the Hungarian Academy of Sciences.

2 Burke, Languages, 44. 
of language in binding together a group. In this case, the people, who were bound together formed 'a community of ideas' or an 'imagined community' that was international in scope." 3 The erosion or alteration of this ambition, for various reasons, was reflected in changes to the hegemony of Latin. However, the author explores the local aspect of this process in less detail. One very productive approach is to interpret the eighteenth-century use of Latin as an element of community identity, following Burke; or as a symbol, as suggested by Françoise Waquet. ${ }^{4}$ Nevertheless, I believe that the function of identity formation is not necessarily 'international in scope.' Even when interpreted as a symbol, its function was not exclusively the representation (and subsequent elimination) of a 'hegemonic cultural model' among contemporaries. ${ }^{5}$ While I would therefore agree with these suggestions and models, I believe that, with targeted research, the models can be honed and made more useful at the level of local processes. ${ }^{6}$ A review of eighteenth-century Latin-language journalism in Hungary, such as I offer below, can be extremely valuable in this respect.

\section{Latin Journalism before 1790}

Latin-language publications have a special role in the history of eighteenthcentury journalism in Hungary. Tellingly, the first successful attempt to create a newspaper in Hungary concerned the Latin-language Mercurius Hungaricus / Mercurius Veridicus ex Hungaria, which appeared between 1705 and 1710 on a

3 Burke, Languages, 44.

4 F. Waquet, Latin or the Empire of a Sign (London and New York 2001).

5 "Latin disappeared because it no longer meant anything to the contemporary world. All that it had once embodied - a certain idea of humanity, a form of discrimination, a system of power, an universal outlook, with an underlying conception of society, its order, its standards - no longer carried meaning, or was being said differently, and the hegemonic cultural model to which it referred was now victoriously rivalled." Waquet, Latin, 273.

6 With respect to Hungary, the results of such incomplete research are published in: F. Bíró, ed., Tanulmányok a magyar nyelv ügyének 18. századi történetéból [Studies on the history of the cause of the Hungarian language in the $18^{\text {th }}$ century] (Budapest 2005). In this connection, Jerzy Axer published research on the use of Latin in Poland, which has been partially taken into account by Waquet. See J. Axer, "Latin in Poland and East-Central Europe: Continuity and Discontinuity." European Review, 2 (1994), 305-309; J. Axer, ed., Eacina jako język elit (Warsaw 2004); id., "Latin as the Second Language of the Polish Republic's Noblemen's Nation," in Terra marique. The Cultural Intercourse Between the European Center and Periphery in Modern Time, ed. by Jan Kieniewicz (Warsaw 2001), 59-63. 
more or less regular basis. ${ }^{7}$ Its purpose was to promote the diplomatic goals of Prince Ferenc Rákóczi, who was leading the Hungarian War of Independence. The first issue was probably published in Hungarian, since the target readership was the Hungarian public and the newspaper's task was to balance the one-sided information provided by the Wienerisches Diarium. ${ }^{8}$

After the first issue, Hungarian was dropped in favour of Latin. This rapid transition to Latin was prompted by two factors. On the one hand, Latin was the language of law and public life in the Kingdom of Hungary, and as such it symbolised the historical tradition of Hungary's independence, making it a suitable vehicle for representing the struggle for independence. This is clearly demonstrated by the fact that, while copies of Cursor Ordinarius, the Latinlanguage gazette published since 1677 in Vienna, are rarely to be found in German and Austrian public collections, many copies have been preserved in Hungary, which suggests that, being published in Latin, it was most popular on Hungarian territory within the Habsburg Empire, even if it expressly represented the interests of the court. ${ }^{9}$ On the other hand, the Cursor Ordinarius may have provided its editors with proof that the use of the Latin language could also be appropriate for diplomatic and propagandistic purposes. At this time, Latin was still so prevalent in Europe that a Latin-language publication was regarded as capable of informing and influencing even foreign royal courts. ${ }^{10}$ This also supports Burke's assertion that, in the fifteenth to seventeenth centuries, Latin was one of the most important languages in European diplomacy,

7 Photographs of all extant issues of Mercurius, as well as studies and information about its launch, can be found on the website of the National Széchényi Library: Mercurius Veridicus ex Hungaria, available at http://epa.oszk.hu/oogoo/oogo4/mv.html, accessed on 7 June 2013 .

8 Launched in 1703, issues of the Viennese periodical can be viewed on the homepage of Österreichische Nationalbibliothek: Wiener Zeitung, available at http://anno.onb.ac.at/ cgi-content/anno?apm=0\&aid=wrz, accessed on o7 June 2013.

$9 \quad$ H. W. Lang, “Der 'Cursor Ordinarius,' eine neuabgefundene Wiener Lateinische Zeitung," Magyar Könyvszemle 92 (1976), 201-210, available at http://epa.oszk.hu/ooooo/ooo21/ $00295 /$ pdf/, accessed on 7 June 2013.

10 Besides Hungarian public collections, currently known copies of Mercurius Veridicus can be found in Berlin, in the Preussisches Geheimes Staadstarchiv, R. XI. 279. Fasc. 11, Fol. 65-70, and in Paris, in the Archives du Ministère des Affaires Étrangères, Correspondance politique: Hongrie. Tome 14, Fol. 113-114. The related information is summarised in the following study: Á. Hangodi, "A Vendomosti és a Mercurius Veridicus" [The Vendomosti and the Mercurius Veridicus], Magyar Könyvszemle 112 (1996), 97-106, at $105^{-106 .}$ 
thus in the early eighteenth century Latin could still have been regarded as a useful language in this respect. ${ }^{11}$ Nevertheless, it is significant that this was the first as well as the last time that a diplomatic objective, along with diplomats as a target audience, appeared in the history of Latin-language journalism in Hungary. Latin appeared later with this function, rather in connection with political tracts, although in Hungarian pamphlet literature, which was on the upsurge in the 179os, the Hungarian and German languages were already increasingly being used at the expense of Latin. In contrast to the demise of Latin as the language of diplomacy, the link between the Latin language and the constitutional independence of the Kingdom of Hungary, its particular degree of autonomy and the aristocratic community that represented it, seems to have lasted longer. It can be argued that the switch to Latin following the first issue of Mercurius Hungaricus not only served diplomatic goals, but that Latin also seemed more suitable as an intermediary language among the various strata of the Hungarian nobility, which comprised a wide range of different native languages.

Published by the scholar Matthias Bel between 1721 and 1722, Nova Posoniensia was chronologically the next Latin-language newspaper in Hungary. ${ }^{12}$ The title itself indicates an intentional identification with traditional European Latinlanguage journalism, and specifically with the scholarly tradition represented by the Leipzig journal Acta eruditorum. The use of Latin was therefore justified by the fact that the lingua franca of European science at this time was still primarily Latin. ${ }^{13}$ In around 1700, the Leipzig publishers of Acta eruditorum stated as their main reason for choosing Latin as the language of their journals that Latin was "the common language of the Republic of the Letters." ${ }^{14}$ Indeed, at the Evangelical lyceum in Pressburg, Bel encouraged his students to read the Acta

11 Burke, Languages, 45-46. On the use of Latin as the language of diplomacy at the beginning of the $18^{\text {th }}$ century, see also: F. Waquet, "Latin," in Finding Europe: Discourses in Margins, Communities, Images, ed. by A. Molho and D. R. Curto (Berghahn 2007), 359-376, at 369-370; A. Jönsson, "The Rise and Fall of Latin in Swedish $17^{\text {th }}$-century Politics and Diplomacy," in Terra marique, 25-34.

12 For a detailed introduction to Nova Posoniensia see B. Dezsényi, "Die Anfänge des Zeitungswesens und des Zeitungslesens in Ungarn. Nova Posoniensia 1721-1722," Acta Litteraria Academiae Scientiarum Hungariae 13 (1971), 55-81.

13 P. Casanova, The World Republic of Letters (Harvard 2004), 45-57.

14 The circumstances are explained in detail in the chapter "The choice of the Latin language" in H. Laeven, The Acta eruditorum under the Editorship of Otto Mencke (Amsterdam 1990), 51-53. 
eruditorum from 1718. This is a further indication that Bel, who had graduated from Halle, was attempting to put journalism into the service of education, following the teaching and example of his former professor, Francke. ${ }^{15}$ The goal of Nova Posoniensia was therefore not only to convey the activities and achievements of Hungarian scientific circles to the international scientific community, and vice versa. It was also a medium in the sense that its news section conveyed to students in Pressburg news from the wider world and from their homeland, augmenting their geographical, historical and cultural awareness. ${ }^{16}$ This goal is clearly reflected in the newspaper's supplement Syllabus, which listed the most important political and cultural events of the month, scientific discoveries, as well as the work of scientific societies. The editor even included a glossary to the news, explaining lesser-known historical and geographical concepts. The use of Latin was linked to this objective, since Latin was the language of instruction at the Pressburg lyceum, attended by large numbers of Hungarian-, German- and Slovak-speaking students from Hungary. Finally, collecting materials for publication in Nova Posoniensia was an integral part

15 "At the end of the $17^{\text {th }}$ century, in Glaucha near Halle, August Hermann Francke established a Pedagogium for noble youth, the curriculum of which included reading newspapers once a week - namely on Mondays between 3 and 5 pm. From the Latin-language newspapers, students were not only able to learn of new discoveries, Francke argues, but can also broaden their knowledge of geography, history and genealogy. In chapter 4 of the curriculum, Francke also provides for the reading of German newspapers to supplement geographical studies. As a methodological proposal he suggests that teachers should read the newspapers before the class and should call students' attention at the beginning of the class to the most important things, in the interests of optimal time management. The school also taught the French language, and as a supplement the curriculum required the reading of French-language newspapers in the period from 1699 to 1702 . By reading various newspapers at school, Francke certainly came to the conclusion that a newspaper-established primarily for educational purposes-might achieve the goal more effectively, thus he launched his own paper, the Hallische Zeitung, in 1708." K. Fehér, "Iskolai újságolvasás Magyarországon a 18. században" [Reading newspapers in schools in Hungary in the $18^{\text {th }}$ century], Magyar Könyvszemle 120 (2004), 131-150, at 131-132. See also A. Bierbach, Die Geschichte der Halleschen Zeitung, Landeszeitung für die Provinz Sachen, für Anhalt und Thüringen. Eine Denkschrift aus Anlaß der 2oojährigen Bestehens der Zeitung am 25. Juni 1908 (Halle/Saale 1908).

16 According to Ephemerides Scholasticae, the diary of a study published by the Evangelical Lyceum in Bratislava, reading newspapers is primarily intended to enhance students' skills in languages, history and geography. This is explained in detail in Fehér, "Iskolai újságolvasás," 133 . 
of Bel's regional studies research project. ${ }^{17}$ As the focus of this project was a description of Hungary and the Hungarian population as a whole, it had to take into account the linguistic diversity of Hungary, and consequently the linguistic diversity of its prospective readers. Hungarian, German, and Bel's native Slovak would not have offered an appropriately neutral solution to this problem, as each would have given preference to a particular language/ethnic group. The role of the Latin language was therefore appreciated, in that it was capable of connecting and addressing as a single community the various ethnic groups of Hungary that spoke different languages. As such, Latin implicitly came to represent in journalism a kind of regional community-based national identity, the so-called Hungarus consciousness. ${ }^{18}$ The editor of Nova Posoniensia was exploiting three functions of Latin simultaneously: firstly, he was using it as the lingua franca of the Republic of Letters; secondly, it was the official language of education; and thirdly, it was able to address as a community ethnic groups in Pressburg and in Hungary.

The publisher of the next Latin-language periodical seems to have chosen Latin because it was the language of education. Since the 1777 Ratio Educationis, Queen Maria Theresa's decree on education, ${ }^{19}$ prescribed the reading of newspapers for educational purposes, there is every reason to associate with it the Ephemerides Vindobonenses, which was launched in Vienna by József Keresztury (Josip Keresturi) in $1776 .{ }^{20}$ This association can be supported by a number of arguments. The invitation for subscriptions specifically highlights the paper's intention to provide useful reading matter for students. It was published twice a week, which, according to the Ratio Educationis, was precisely

17 The results of Matthias Bel's statistical research are summarised in the volumes of Notitia Hungariae novae historico geographica, 5 vols. (Vienna 1735-1742). For its presentation, see I. Soós, "Die 'Notitia' von Matthias Bel un das Bild des neuen Ungarns, mit besonderer Berücksichtigung der Komitate von West-Ungarn (Ödenburg, Eisenburg, Sala)," in Internationales Kulturhistorisches Symposium Mogersdorf 2003. Neuzeitliche Reisekultur im pannonischen Raum bis zur Mitte des 19 Jahrhunderts (Maribor 2005), 47-68. I. Zombori, "Bél Mátyás és a Notitia Hungariae" [Matthias Bel and the Notitia Hungariae], Móra Ferenc Múzeum évkönyve (1980), 113-162.

18 On the history of the Hungarus mentality, see the chapter by Ambrus Miskolczy in the present volume.

19 On the political background of the era, its rulers and their decrees, see É. H. Balázs, Hungary and the Habsburgs, 1765-180o: An Experiment in Enlightened Absolutism (Budapest 1997). For the Ratio educationis see the chapter by T. Shek Brnardić in this volume.

20 The journal is described in detail by Gy. Kókay, Az Ephemerides Vindobonenses, 1776-1785 (Budapest 1958) (Az Országos Széchényi Könyvtár kiadványai [Publication of the National Széchényi Library], 43). 
how often students in secondary schools were obliged to read a newspaper. The journal comprised two sections; Res politicae featured mainly Viennese and Imperial news, while Res litterariae included book reviews and educational articles. Among other things, the newspaper provided detailed articles about the implementation of the Ratio Educationis, the moving of the university from Pressburg to Buda, as well as Sámuel Tessedik's progressive school of economics in Szarvas. In 1785, an editorial announced the termination of the paper, referring to Joseph II's decree on the German language, which promoted German as the official language of instruction in place of Latin, among the reasons for its demise.

However, the editor also implies that, in addition to educational purposes, there were other reasons for using Latin. On the one hand, the paper was intended for educated people, and the intention was to popularise science:

We, the writers of the Ephemerides, have no intention of expressing an opinion about the reviewed books. Those who think otherwise should remember that our journal is not intended for the general public, but that we have launched a partly political, partly scholarly journal. We referred to this in our programme: Whether written in prose or verse, our goal is to keep our eyes on literary things, new achievements in the arts and sciences-especially of an economic nature, from which most benefits usually arise-and those that are fitting to the development of talent and for educating people towards decency. Literary journals, such as the Journal Encyclopédique, therefore mix political with literary news. And this is why we have written in Latin: it is not common people but educated people who understand Latin. ${ }^{21}$

On the other hand, he referred to the political profile of the paper, since it was aimed not only at Hungarians but at all those living in the Habsburg Empire,

21 "Nostrum autem, qui Ephemerides scribimus, non est, de libris in publicum datis iudicium ferre. Qui ita ratiocinantur, meminerint, nos non vulgares, sed partim politicas, partim eruditas Ephemerides scribere instituisse. Ita enim in Programmate, quo Ephemerides has denunciavimus, locuti sumus: Res etiam literarias, libros editos, nova in quocunque artium ac scientiarum genere inventa, oeconomica praecipue, ex quibus maximi plerumque fructus percipi solent, tum ea quoque, quae ad acuenda ingenia, animosque ad humanitatem infirmandos sive libera, sive adstricta numeris Oratione scribuntur, recensere (non iudicare tantummodo) nobis animus est. Hac ratione etiam Ephemerides literariae, ut Journal Encyclopedique, res politicas literariis immiscent. Et sane talem vel propter ipsam, qua scribimus, linguam instituti nostri rationem esse oportuit, cum utique non vulgus, sed eruditi solum latinam linguam norint." Ephemerides Vindobonenses (1777), 165-166. 
especially Croats, Slavonians, Dalmatians and Transylvanians. He made special mention of Poles as potential readers - in a good sense, since the Latin language still played a very important role at this time in Polish culture. ${ }^{22} \mathrm{He}$ clearly treats as a community the inhabitants of one particular area, namely the Habsburg Empire, regardless of their native language. It is no coincidence that the cover page of the magazine featured the imperial eagle and the coat of arms of the House of Habsburg-Lorraine, flanked by Chronos/Saturn with wings and scythe, and Mercury, the god of messengers. The Ephemerides Vindobonenses thus aspired to be representative of some kind of imperial community consciousness via the medium of the Latin language.

It is worth noting that, besides Hungarians, the large number of Croat readers, for whom Latin was a second language, are brought to the fore. At the same time, native German readers get only a brief mention, probably because of the large number of German-language papers available. ${ }^{23}$ The stress on the Croatian readership indicates that, for them, Latin represented as much of a historical tradition as for Hungarians and other people living in Hungary, for whom Latin was the language of communication at the various levels of the political institutional system. ${ }^{24}$ When the diet of $1790-1792$ endeavoured to reinforce the Hungarian language, it was this shared historical tradition that remained disrespected, leading to a conflict between different national groups. For members of the Croatian nobility, who participated in the work of Hungarian political institutions, replacing Latin with Hungarian as official language was unacceptable, as this would mean being condemned

22 The relationship between the Hungarian and Polish neo-Latin tradition is explored in detail by J. Axer, "Central-Eastern Europe," in A Companion to the Classical Tradition, ed. by C. W. Kallendorf (Malden, Mass. 2007), 132-155.

23 However, it is not unreasonable to assume a German-speaking readership, since Latin had traditionally been used as a medium between the German and Hungarian cultures. Cf. É. Knapp and G. Tüskés, "Deutsch-ungarische Verbindungen auf dem Gebiet der lateinischen Literatur im 17. Jahrhundert," in Acta conventus neo-latini Budapestinensis: Proceedings of the Thirteenth International Congress of Neo-Latin Studies, Budapest, 6-12 August 2006, ed. by R. Svhnur and J. P. Barea (Tempe, A.Z. 2010), 775-787.

24 The orientation towards the Croatian reading public may be explained by the fact, that Keresztury came from a Croatian family from Stridóvár. Accordingly, his work has for a long time been a subject of scholarly interest in Croatia. See e.g. M. Korade, "Obrana hrvatstva u djelima Josipa Keresturija," [Defence of the Croatian identity in the works of Josip Keresturi] in Dani Hvarskog kazališta: hrvatsko kajkavsko pjesništvo do preporoda, ed. by N. Batušić (Split 1993), 154-163. 


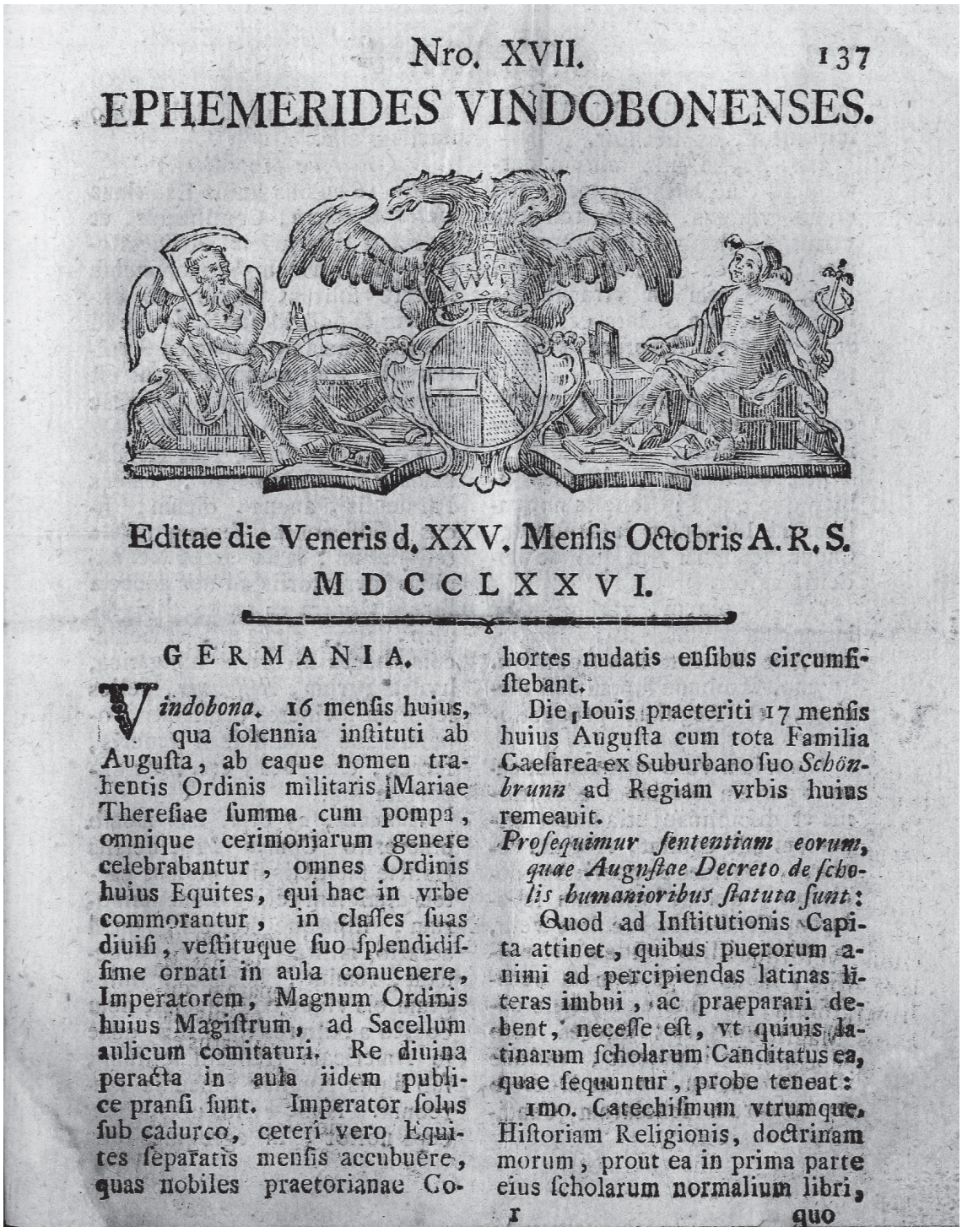

FIGURE 7.1 Title page of the Ephemerides Vindobonenses.

COURTESY OF NATIONAL SZÉCHÉNYI LIBRARY (BUDAPEST).

to silence on issues of common concern, or being unilaterally obliged to learn the Hungarian language, as Nicolaus Skerlecz (Nikola Škrlec) explained in his contemporary Latin-language pamphlet on the subject. ${ }^{25}$

25 [N. Skerlecz], Declaratio ex parte nunciorum Regni Croatiae, quoad inducendam Hungaricam linguam (n.p. [1790]). On Skerlecz, see É. H. Balázs, Hungary and the 
Latin was, therefore, partly a mediatory language in the service of education. As such, its target audience comprised mostly students in secondary schools and institutes of higher education along with their teachers and professors. Various manuscript drafts and proposals from 1779-1780 suggested the establishment of a Latin-language newspaper for students by the University of Buda under the working title Ephemerides Budenses. These documents say a great deal about the educational function of Latin-language journalism. ${ }^{26}$ The most interesting among them is a proposal by Pál Makó, ${ }^{27}$ which insists that the specialist journal should not be political but scientific and bibliographic in nature. He suggested using book reviews and descriptions of scientific results to inform foreign countries about Hungarian cultural achievements and familiarise Hungarian audiences with foreign achievements. The attempt to establish the university paper was not successful. It is clear that, in the 1780 s and 1790 , the German language was seen as more suitable for achieving these goals: This view is supported by Márton György Kovachich's Merkur von Ungarn, ${ }^{28}$ and Lajos János Schedius's (Johann Ludwig von Schedius's) Literarischer Anzeiger. ${ }^{29}$ Published in Banská Štiavnica (Selmecbánya) between 1793 and 1803, the periodical Novi Ecclesiastico-Scholastici Annales Evangelicorum August. et Helvet. Confessionis in Austriaca Monarchia is also of interest in this respect. ${ }^{30}$ Its editor, the Lutheran minister Sámuel Ambrózy, who graduated from the University of Jena, cleverly combined an educational objective with the paper's clerical target audience, and, like the Ephemerides Vindobonenses he placed the publication in an imperial context. His example illustrates how Lutheran clerics in

Habsburgs 1765-180o. An Experiment in Enlightened Absolutism (Budapest 1997), 316-318. On the opinions and writings of Croatian parliamentary deputies on this particular subject, see Gy. Miskolczy, A horvát kérdés története és irományai a rendi állam korában [The history and documents of the Croatian question in the age of the estates], 2 vols. (Budapest 1927); I. Mikó, A magyar államnyelv kérdése a magyar országgyúlés elött 1790-1825 [The issue of Hungarian in the Hungarian parliament] (Kolozsvár 1943), 9-12.

26 These have prevailed in the English section of the National Archives. For a detailed presentation see D. F. Csanak, "A Ratio Educationis és az iskolai újságok" [Ratio Educationis and school newspapers], Magyar Könyvszemle 91 (1975), 243-261.

27 Hungarian National Archive, A 39 Acta generalia 1779/5150. Details are published by Csanak, A Ratio, 247-249.

28 Merkur von Ungarn, oder Literaturzeitung das Königreichs Ungarn (1786-1787). On Kovachich see É. V. Windisch, Kovachich Márton György, a forráskutató [M. Gy. K., researcher of sources] (Budapest 1998).

29 Literarischer Anzeiger für Ungern (1798-1799).

30 On Sámuel Ambrózy's Latin journal, see Gy. Kókay, “Az első magyarországi egyházi folyóirat történetéhez" [On the story of the first Hungarian ecclesiastical paper], Magyar Könyvszemle 113 (1997), 95-97. 
Hungary still preferred Latin - a claim that is supported by an examination of archival documents of the contemporary Lutheran Church. (The hold of Latin within the Catholic Church is of course less surprising. ${ }^{31}$ ) It was, most importantly, the linguistic (German, Slovak, Hungarian) diversity of the Lutheran Church that explains the weaker impact of Protestantism's otherwise characteristic cult of the vernacular.

In any case, the use of Latin in journalism as the common language of the Republic of Letters had long provided access to international scientific discourse. The fact that Latin was regarded as a workable alternative, even in the second half of the century, is clearly illustrated by Maximilian Hell's journal of astronomy, Ephemerides Astronomicae ad Meridianum Vindobonensem, published annually between 1757 and 1792. The journal contained primarily astronomical tables, but also featured short studies and reports on the subject. ${ }^{32}$ However, this example also demonstrates that scientific journalism in Latin no longer aimed at the promotion of science, but was increasingly limited to a range of specialist academic journals: the target audience comprised skilled specialists from various scientific disciplines.

The choice of Latin also had a political dimension. While, in the case of popular journals, Latin was used as a kind of 'prestige language' for the interdependent forms (i.e. educational and disciplinary) of scientific communication, ${ }^{33}$

31 The proportions of the different languages of documents in Archivum Generalis Ecclesiae of the Central Archives of the Lutheran Church in Hungary is telling in this respect.

"Hell's main work at the observatory was to publish each year the Ephemerides Astronomicae (astronomical ephemerides) - that is, astronomical almanacs with the precise time on every day of the year of sunrise and sunset, the positions of the moon and planets and other astronomical data. This type of publication, which was to become for a long time a common procedure of observatories, had only begun to be published in the Paris observatory a few years before. The first volume of $25^{\circ}$ pages, written in Latin, appeared in 1757; it also included other astronomical observations and scientific results. This was the first publication of this type in German-speaking countries. Hell published 37 volumes of ephemerides between 1757 and 1792. In this work he was helped by his co-workers and students, among them Franz Triesnecker (1745-1809) and Anton Pilgram (1730-1793)." A. Udías, Searching the Heavens and the Earth: the History of Jesuit Observatories (Dordrecht 2003), 27. On Hell's scientific-political goals, see L. Kontler, "Politicians, Patriot and Plotters: Unlikely Debates Occasioned by Maximilian Hell's Venus Transit Expedition of 1769," The Journal of Astronomical Data 19 (2013), 83-93. For more on the journal and Hell, see the chapter by László Kontler and Per Pippin Aspaas in this volume.

33 The qualification "prestige language" is certainly applicable to these functions of Latin. Cf. H. Kahane, “A typology of the Prestige Language," Language 62 (1986), 495-508. 
the various intentions of politically motivated Latin journalism differed from, and in some cases even contradicted, one another.

As we have seen above, Latin became, on the one hand, the symbol of an independent Hungarian statehood and of constitutional independence, making it a suitable vehicle for expressing distance from the Habsburg emperors as well as aspirations to independence. This trait is clearly revealed in the protest against Joseph II's 1784 decree that made German the official language in Hungary: the counties protested largely by arguing for Latin rather than Hungarian as the state language. ${ }^{34}$ Thus it was not merely the case, as mentioned in Burke's monograph, that Latin was the common language of officialdom. In Hungary, due to its traditional role in public life Latin could appropriately become one of the symbols of the feudal political community that was the Hungarian nobility. On the other hand, the Latin language was considered a suitable means of representing multilingual Hungary as a cultural and political unity within the Habsburg Empire. Latin therefore became particularly important for nonHungarian groups, in particular members of the German- or Slovak-speaking bourgeoisie of Hungary, who, boasting of outstanding cultural achievements, wished to acquire political rights (being a perfect example). In this case, Latin again functions as a symbol of community, as the representation of the socalled Hungarus consciousness with its medieval roots. ${ }^{35}$ Due to the many languages used in Hungary, the ideal medium of this common patriotic feeling, whether in scientific works or journals, was Latin. Finally, the example of the Ephemerides Vindobonenses demonstrates that Latin was also considered an ideal medium primarily for those court-related efforts that aimed to represent the various linguistic and identity groups of the Habsburg Empire by means of a politically and culturally grounded sense of community. In other words,

34 Based on detailed archival research, it is verified by I. Soós, "II. József német nyelvrendelete és a hivatalos Magyarország" [The language decree of Joseph II and the official Hungary], in Tanulmányok a magyar nyelv ügyének 18. századi történetéból, ed. by F. Bíró (Budapest 2005), 261-301.

See fn. 19 and I. Soós, "Értelmiségi minták és a Hungarus-tudat / Modely prislusnikov inteligencie a povedomie Hungarus" [Intellectual models and the Hungarus consciousness], in Regionálna a národná indentita v madarsjkej a slovenskej histórii 18.-20. storocia / Regionális és nemzeti identitásformák a 18-20. századi magyar és szlovák történelemben, ed. by Z. S. Sutaj and L. Szarka (Presov 2007), 10-20. For the 'Hungarus intellectuals,' the Latin language was, among other things, a cultural context, by which they wished to represent the whole of Hungarian culture as a unity. Cf. É. Knapp and G. Tüskés, "Forerunners of Neo-Latin philology and national history of literature: the $18^{\text {th }}$ century," in Companion to the History of Neo-Latin Studies in Hungary, ed. by I. Bartók (Budapest 2005), 37-54. 
Latin-language media suited the goals of Hungarian feudal politics, which emphasised constitutional independence, as well as those of the Habsburg court, which aimed to reduce imperial disparities, or at least to cover them up.

However, in the 1790 s feudal politics started increasingly to favour Hungarian as the official language of Hungary. In court politics, as indicated by the language decree of Joseph II, aspirations towards the generalisation of the German language, and at the same time towards the linguistic unification of the Empire, appear from the 1780 s. Even those endeavours aimed at strengthening a sense of imperial identity by cultural means tended to prefer the German language. However, faced with the strong opposition of the Hungarian estates in 1790, and later in the crisis of the Napoleonic Wars, the court was forced to make concessions, first with respect to Latin and later with respect to Hungarian as official language. ${ }^{36}$

In popular scientific journalism vernaculars were gaining ground, while Latin was confined to strictly scientific organs. Published between 1790 and 1793, the Latin-language Ephemerides Budenses can be considered a rarity, and almost as an anachronism, in terms of language choice. ${ }^{37}$ It may therefore be instructive to examine the reasons behind the unusual choice of language in the case of the last major Latin paper in Hungary.

\section{The Curious Case of the Ephemerides Budenses}

Significantly, the title Ephemerides Budenses, as I suggested above, had already been considered a few years earlier as the title of a journal to be published by the university for Hungarian scientists and students for scientific and educational purposes. Besides, the Ephemerides had strong associations with the Viennese Ephemerides Vindobonenses, both in terms of the Latin wording of the title, and in terms of its main sections (Politica, Litteraria). The political section often featured news from Vienna, while the cultural section frequently contained educational news. The typographical similarity was reinforced by the use of an $A_{5}$ format and ornate frontispiece. The journal's image therefore

36 See Gy. Szekfü, Iratok a magyar államnyelv kérdésének történetéhez 1790-1848 [Documents on the history of the status of Hungarian as official language, 1790-1848] (Budapest 1926), $64-65$.

37 Ephemerides Budenses, 1790-1793. Edited by Mihály Tertina (1790), Pál Spielenberg (1790-1793). The first year is available on the website of the National Széchényi Library: http://epa.oszk.hu/html/vgi/boritolapuj.phtml?id=01024, accessed on 07 June 2013. 
suggests that it was published as part of an existing tradition that was officially supported and recognised by the court.

It is also noteworthy that the date and location of the launch of the journal coincide with the 1790-1792 diet, where the explicit goal of the Hungarian estates was to strengthen and extend Hungarian constitutional autonomy. The Ephemerides published continuous and detailed news about this diet, and its tone was far from loyal to the court. Lack of loyalty in tone is best demonstrated by the presence of lines that are struck through, especially in 1792-1793, indicating the censoring of the journal's content. News items containing such deletions had probably attempted to provide information about certain events of the French Revolution. The journal's frontispiece is visually very expressive. Although it is typographically similar to the emblem used in the Ephemerides Vindobonenses, it is very different in terms of content. Among the many crests that surround the emblem, the largest is the Hungarian coat of arms in the centre, while the Croatian coat of arms is also given special place. At the centre of the emblem is the Royal Castle of Buda: the remains of the Renaissance palace, built in the fifteenth century by King Matthias, which was at that time perhaps the most impressive architectural symbol of the tradition of a previously independent Hungarian statehood.

It is also remarkable that, while the Ephemerides Vindobonenses specifically intended to use Latin as a bridge to link the multilingual residents of the Habsburg Empire, and the Kingdom of Hungary within it, the Ephemerides Budenses apparently represents entirely different linguistic priorities. An examination of the journal's news and book reviews from this perspective reveals the outlines of an explicit programme of language cultivation, with a focus on the Hungarian language. Published as an appendix to the Ephemerides, and written by the then editor Paul Spielenberg, the programmatic statement that became known as Monita de Lingua et theatro hungarico stabiliendo is a concise summary of this programme. ${ }^{38}$ Spielenberg establishes that the development of the Hungarian language is an essential condition for the development of the Hungarian sciences, the arts, industry, commerce, and national existence in general. It is followed by a list of the steps of a language cultivation programme. The first step is the elimination of multilingualism in Hungary. According to the author, in non-Hungarian-speaking villages and towns it should be a legal requirement that small children be looked after by Hungarian-speaking nannies and servants so that they learn Hungarian

38 Ephemerides Budenses [hereafter: $E B$ ] (29 Oct. 1792), appendix. It is no coincidence that in 1837 this programme was translated into Hungarian: this was the time when its radical stance on behalf of Hungarian found followers (translated in Honmüvész [22 Dec. 1837]). 


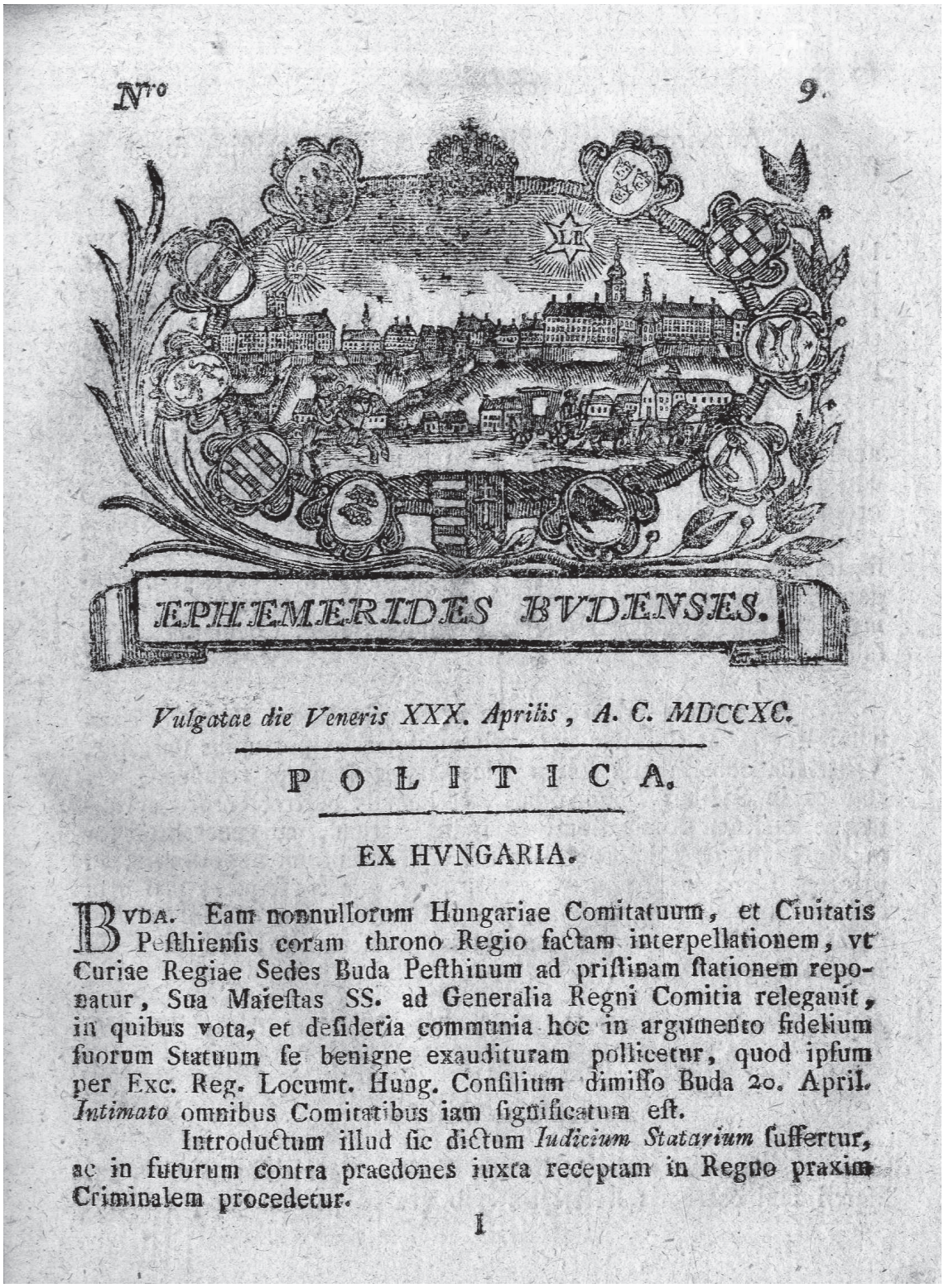

FIGURE 7.2 The title page of the Ephemerides Budenses.

COURTESY OF NATIONAL SZÉCHÉNYI LIBRARY (BUDAPEST).

through mutual communication, especially if this is enhanced by the establishment of appropriate local schools. The next step is to make Hungarian the official language, especially in public life - in other words, to introduce the use of Hungarian in the county and national diets, in the administration, and in 
the judicial system. Finally, the position of Hungarian should be strengthened in the cultural sphere. The means for this would be the construction of theatres for Hungarian-language companies, and the creation of philological societies.

The statement of the programme's aims was followed by an overview of the potential obstacles. On the one hand, the author makes clear that the programme would take at least five to ten years to accomplish, and that the results would only be enjoyed by the next generation. On the other hand, he refers to the potential response of the country's non-Hungarian-speaking population. Spielenberg assumed that the national consciousness of Croatia-Slavonia was based primarily on legal privileges, while with respect to Transylvania he took only the language identity of the nobility into account, thus he presents this obstacle as being far smaller than it actually was.

The outlined programme was influential in terms of the thematic composition of the Ephemerides. ${ }^{39}$ The journal contained a remarkably large proportion of news and reviews related to the development of the Hungarian language: almost every issue included at least one item on the subject. The related news, announcements and reviews published in the Ephemerides can be divided into eight main thematic categories. First of all there were general articles on the situation of the Hungarian language and the cause of language cultivation, which were usually written with programmatic intent.

Another important thematic group comprised articles on the situation and development of Hungarian-language literature. Pál Spielenberg's overview of the situation of Hungarian poetry deserves special mention here: it emphasised, along with linguistic and prosodic issues, the importance of the cultivation and teaching of aesthetics in the development of Hungarian poetic language. The diagram below illustrates the distribution of reviewed books according to language.

What is of interest here is the fact that a significant change in the number of printed publications in Hungary occurs in around 1790 - the time when the previously dominant Latin was being replaced by Hungarian-language works. Between 1781 and 1790, published works comprised 36.8 per cent Latin, 33.8 per cent Hungarian, 23.3 per cent German, 5.4 per cent Slavic and 0.7 per cent other, while between 1791 and 1800 the proportions were 37.3 per cent Latin, 40.4 per cent Hungarian, 16.9 per cent German, 5.1 per cent Slavic and

39 For a detailed demonstration supported by quotes see my earlier study: P. Balogh and M. Szilágyi, “...quibus Linguae Hungaricae propagatio cordi est: Az Ephemerides Budenses a magyar nyelvhasználat kérdéseiről” [ . . to those who cherish the spreading of the Hungarian language: The Ephemerides on the issues of using Hungarian language], in Bíró, Tanulmányok a magyar nyelv, 23-69. 


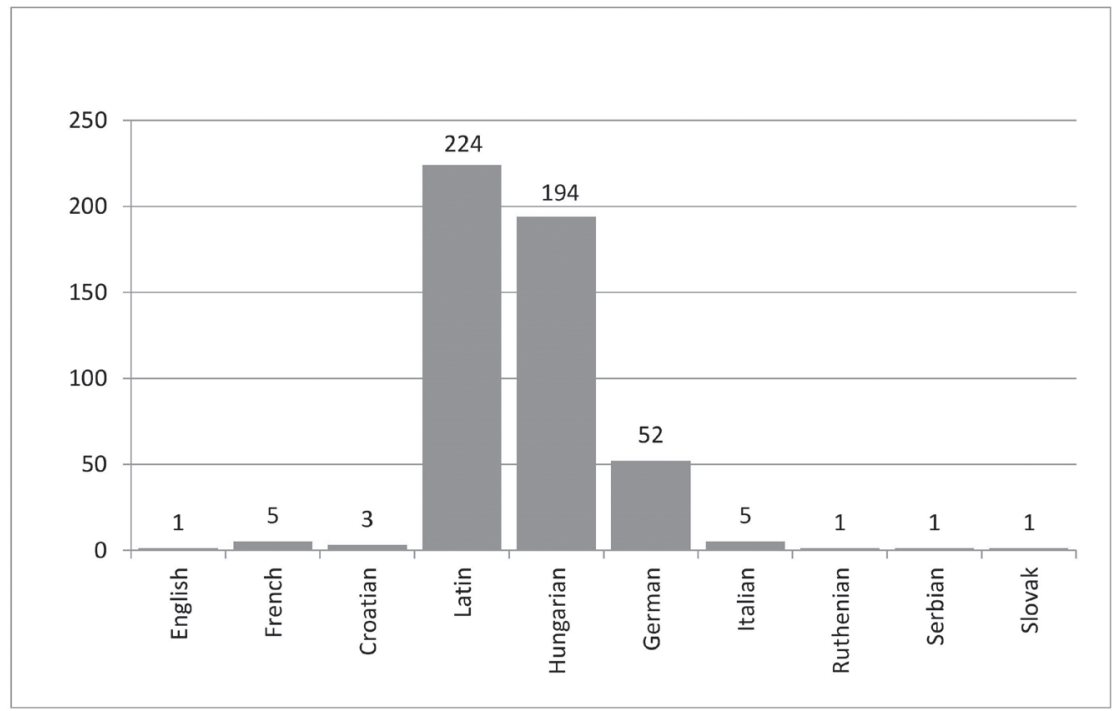

DIAGRAM 2 The language of books reviewed in the Ephemerides Budenses.

0.3 per cent other. ${ }^{40}$ The reviews featured in the Ephemerides follow this trend with striking sensitivity, and despite being a Latin-language journal it reflects no preference for Latin-language literature. Rather than trying to cover it up, it in fact underlines the increasingly significant number and proportion of Hungarian-language published works. These data also confirm that the Ephemerides paid particular attention to contemporary Hungarian-language literature and endeavoured to promote its development.

I have grouped into another category those writings that concern the relationship between the Hungarian language and the sciences. On the one hand, these works attempt to demonstrate that various disciplines can be practised and propagated in Hungarian. On the other hand, they reject the creation of grammar books and monolingual dictionaries, as debates over such things would only delay the rendering of scientific language into Hungarian. Instead, they regard as best practice the Hungarian translation or revision of technical or popular scientific works.

The publications examine the practical conditions for this programme, touching upon issues such as the institutional background of language cultivation. The main question was whether learned societies (or an academy)

$40 \quad$ For detailed data, see Cs. Csapodi, "A magyarországi nyomtatványok nyelvi megoszlása 1800-ig" [The language distribution of Hungarian printed matters before 180o], Magyar Könyvszemle 70 (1946), 98-104. 
could be more efficient than a patronage system in supporting the development of the Hungarian language. The Ephemerides clearly advocates the establishment of societies or an academic institution.

Education is another priority area for the praxis of language cultivation, and another group of articles comprises news on the language used in the education system. The programme outlined in the journal targets the exclusive and primary use of the Hungarian language in education in Hungary. The possibility of minority language education is mentioned, but only to support the teaching of Hungarian. Latin is interpreted as a cultural code that provides access to the cultural patterns of ancient art, while knowledge of German is apparently fitted into the utilitarian requirement for learning modern European languages.

Another group of articles explore a theme that is also relevant to the practice of language cultivation: They include writings on the development of Hungarian-language theatre, news about Hungary's first theatrical company in Pest-Buda, and appeals on its behalf.

Other articles touch on the social and political dimensions beyond the cultivation of language. They illustrate attempts at and options for promoting Hungarian as an official language. According to reports in the Ephemerides, this was a clear-cut objective. The concept of introducing Hungarian as the official language allowed for an independent language area only in Croatia, but this was to be based on the continuity not of the vernacular Croatian language but of Latin. This was obviously related to the legal and historical traditions of independent Croatian feudalism and feudal autonomy.

In closing, it is worth mentioning a topic to which fewer articles are devoted, but which is noticeably present, mostly in connection with the everyday use and usability of the Hungarian language. Even if not presented as a problem, and even if not emphasised, the need to use Hungarian as the language of conversation and religion is also referred to in pages of the Ephemerides.

In this context, the obvious question is why the Ephemerides Budenses chose Latin as intermediary language for an ostensibly radical Hungarian-language programme. One possible answer is that, by using the Latin language, the aim was to conceal and moderate the radicalism of the programme, particularly with respect to censorship. But do any of the editors provide a direct answer to the question?

At the launch of the journal, its first editor, Mihály Tertina, did not reflect on the problem. ${ }^{41}$ In contrast, it was mentioned on many occasions by Pál

41 For a detailed exploration of Mihály Tertina's editorial practice, see S. A. Tóth, Tertina Mihály a lapszerkesztó és a latin poéta [Mihály Tertina, the journal editor and Latin poet] (Baja 2011). 
Spielenberg, who took over the role of editor a few months later and who remained in this post until the journal ceased publication.

He was forced to reflect on the issue, since the journal's choice of language was not self-evident, even at that time. This is clearly illustrated by an anonymous letter, published in one of the issues of Ephemerides, which contained ironic exhortations addressed to the editor. ${ }^{42}$ Following various other remarks, the author of the letter states that it is not clear why the editor has chosen Latin as the language of his journal. Firstly, he considers it obvious that the editor of the Ephemerides is an apostle of the Hungarian language cause. Secondly, in his opinion the Ephemerides can have few readers who are unable to speak another foreign language apart from Latin and Hungarian. Thirdly, the writer of the letter points out that the editor of the Ephemerides wishes to eliminate the use of Latin in the fields of science, public affairs and justice-but why does he couch his arguments in Latin?

Another attack against Spielenberg was reported in a news item written by the editor himself. ${ }^{43}$ According to this report, in March 1791, during a Germanlanguage theatre performance, a member of the Pest German theatre company made an unscripted, scathing remark about Spielenberg's earlier, unsuccessful efforts as a poet and his current editorial activities: "si, inquit, Poësis mea non iuverit Latina scribam nova." The article in the Ephemerides claimed that this piece of sarcasm was revenge for a report in the Ephemerides about how the leaseholder of the German theatre company had made the situation of the Hungarian company untenable. Interestingly, the use of Latin has a negative connotation in both the reader's letter and the actor's remark, but neither made an apology for the Hungarian language.

The editor's responses were based on two key arguments. ${ }^{44}$ On the one hand, the editor argued that Latin-language journalism had a centuries-old tradition that was now represented in Europe exclusively by his publication. On the other hand, since the language of public life in Hungary had been Latin for eight centuries, Spielenberg believed it to be the most effective means of presenting public affairs in such a way that the news reached everyone interested. In his editorial notes, in which Spielenberg reflects on the continuous decline in subscriber numbers, he frequently formulates a somewhat paradoxical wish: If only the falling number of subscriptions were caused by a growing interest in the Hungarian language ${ }^{45}$ Incidentally, the Ephemerides published

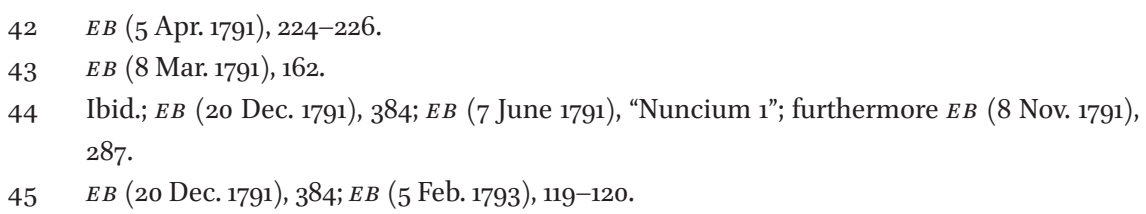


positive reviews of Hungarian-language weeklies and journals, which suggests that it did not regard itself as a competitor in the field of Hungarian-language journalism. ${ }^{46}$ Another anonymous reader's letter in the Ephemerides claimed that the situation could be explained by the general decline in interest in public affairs. ${ }^{47}$ The letter argued that Hungarian-language journals were not being read either, and that the Ephemerides still attracted greater numbers of readers than the number of students studying with the few Hungarian-language professors at the academies (the five higher educational institutions), whose academic chairs had been established with so much effort.

These statements, as well as the type and nature of the articles, suggest that in using the Latin language the editors of the Ephemerides were targeting those readers in Hungary who had primarily learnt about public events in other living European languages (German, Italian or French) but had little access to local news in these languages. This group can hypothetically be identified with teachers and students of newspaper-reading seminars, since, as I mentioned earlier, even though it was not the Ephemerides' main profile, the journal contained news on educational matters and for educational purposes. The target audience also included readers who valued the traditional use of Latin in Hungarian public life perhaps more than the potential spread of the Hungarian language. Finally, it included all those who were living in Hungary but whose native language was not Hungarian and who could not therefore be

46 Cf. Eв (16 Apr. 1790), 40, on Erdélyi Magyar Hírvivő; EB (3 Dec. 179o), on Hadi és Más Nevezetes Történetek; EB (6 Dec. 1791), 352, on Mindenes Gyüjtemény.

"Quod ad nos attinet: mihi dolet summopere, eo res latinas esse loco; ut quarum possessionem nuper in summis Gentis Hungarae laudibus reponebamus, iam negligantur penitus, neque qui labentibus auxiliatricem manum porrigat, inveniatur. Pulcherrimos tuos in conservando latino sermone conatus nulla unquam delebit oblivio. Ego quantum per me stetit lectis tuis 7. Ianuarii Ephemeridibus omnem movi lapidem, nec dubito quin simbolam suam aliqui in huiati Postae officio deposuerint. Apud plerosque adhuc frustra sumus; nec Hungaricae Ephemerides leguntur; atque ego forsitan non fallor, si credam te plures habere lectores, quam omnes linguae Hungaricae (pro qua tamen quantum clamatum?) nuper in Academiis constituti Magistri numerent Auditores." [Concerning ourselves: I am extremely sorry that the cause of Latin has made it to the point that the knowledge of Latin, which not so long ago we counted among the greatest virtues of the Hungarian people, is now utterly neglected and that there is no one to lend a helping hand. Your valiant efforts to preserve the Latin language will never be forgotten. After reading your newspaper from 7 January, I left, so far as possible, no stone unturned, and I doubt not that several others deposited their contributions in the local post office. As far as most people are concerned, it is of no avail. The Hungarian newspapers are not being read either. And perhaps I am right when I believe that you have more readers than there are students of all the newly appointed teachers of the Hungarian language at the academies (for which there was so much clamour).] EB (10 Feb. 1792), 63. 
addressed in the press in Hungarian, but only in Latin. The latter two groups are sociologically clearly defined: the nobles, who used the Latin language as a feudal symbol of the tradition of Hungarian public policy; and the nonHungarian-speaking, mostly civic and intellectual strata, who regarded themselves as Hungarus. From this, it can be concluded that the Ephemerides was intended as the vehicle for an educational Hungarian-language programme. The programme addressed three types of Hungarian audience: students with various mother tongues who were studying journal reading; a non-Hungarian bourgeois readership with Hungarus consciousness; and nobles, who preferred Latin but who were somewhat averse to journal reading. Through the Latin language the journal indirectly popularised among its readership both journal reading and the use of the Hungarian language, by demonstrating (in Latin) its values and benefits. More precisely, Latin was functioning only temporarily as a medium for the multilingual audience of Hungary: its goal was to prepare the ground for Hungarian journalism and to broaden the base of readers who understood and preferred the Hungarian language. The wish, quoted above, that the declining readership of the Ephemerides might be in inverse proportion to the number of readers of Hungarian journals - that is, the wish that the Ephemerides might fill the role of an intermediate re-educational organ in the interests of the Hungarian-language press, is particularly telling in this respect.

This approach, albeit unusual, is not entirely unique to cultural public in late eighteenth-century Hungary. In some respects, Miklós Révai's inaugural speech at the university is a good analogy. On his appointment as head of the Hungarian language department in 1802, the professor delivered an excellent speech on the value of the Hungarian language and the importance of its development and research-in Latin. He did so not only because the official language of university education was Latin, but also out of consideration for the multilingual audience at the solemn event, which could best be persuaded of the value of the Hungarian language in Latin. ${ }^{48}$ Similar parallels can be found in the Latin-language grammar books on the teaching of the Hungarian language, published in the 1780 s and 1790 , which were written for non-Hungarian-speaking students in secondary schools. ${ }^{49}$

48 Miklós Révai, Prolusio I. habita in auspiciis collegii hungarici die VIII. mensis Novembris anno 1802. De prejudicio communi, et noxio, natis hungaris studium linguae patriae non esse necessarium, nil utique audituris, quod non scirent, et in tradendo latini sermonis usu offensis (Pest 1806).

49 For example Gábor Dayka's Latin-language Hungarian grammars that he compiled as a teacher at the Levoča secondary school for his non-Hungarian students. His reason was not only the fact that grammatical terms were more elaborate in Latin than in Hungarian, 


\section{Conclusion}

To conclude, it is worth mentioning another aspect that emerges not from an examination of the text of the journal, but from the correspondence and legacy of its editor, Pál Spielenberg. ${ }^{50}$ Spielenberg's network of connections is important because it encompassed many editors of contemporary Hungarianlanguage journals, and also because he had strong links with a particular Masonic organisation. The Draskovich observance was one of the leading organisations within Hungarian freemasonry. ${ }^{51}$ Spielenberg was a member of the observance's Pest lodge, Magnanimitas. This organisation was independent from the Austrian lodge that was subordinated to the Berlin Mother Lodge. It had its own, independent constitution, and its official language was Latin. This was mainly because the organisation had been founded on Croatian territory, suggesting that Latin must have been a well-functioning medium among its Croatian- and Hungarian-speaking members. On the other hand, the use of the Latin language indicated independence from the Austrian and German lodges, while being functional internationally. The organisation's constitution emphatically encourages members to engage in cultural activity. It was probably no coincidence that many editors of Hungarian-language journals in the 1780 and 1790 s (Ferenc Kazinczy of Orpheus, János Batsányi of Kassai Magyar Múzeum), were members of this organisation, just like Spielenberg and several editors of German journals (such as Lajos János Schedius and Márton György Kovachich). Interestingly, these journals were mutually supportive: Spielenberg's name appeared in the pages of the Magyar Museum, the Ephemerides was cited by Orpheus, and the Ephemerides published detailed and very positive reviews of both Hungarian journals. ${ }^{52}$ Not to mention those

but also that it was an ideal medium for German as well as Slovak students. G. Dayka, "Proludium in Institutiones Linguae Hungaricae," “Ternio Grammaticae Hungaricae 1794," in Dayka Gábor összes müvei, ed. by P. Balogh et al. (Budapest 2009), 243-305.

For a detailed summary of this research and the partial publication of this handwritten legacy, see P. Balogh, "Mozaikok egy hajdanvolt szerkesztő arcképéhez-Spielenberg Pál” [Mosaics to the portrait of an editor of long ago-Pál Spielenberg], in Kolligátum. Tanulmányok a 7o éves Bíró Ferenc tiszteletére, ed. by M. Szilágyi et al. (Budapest 2007), $15^{-44}$.

51 For a presentation of the Draskovich observance, see H. Balázs, Hungary, 72, 138, 270, 305; L. Abafi, Geschichte der Freimaurerei in Österreich-Ungarn, 5 vols. (Budapest 1890-1899), 367-390; W. Read, The Draskovic observance. Eighteenth Century Freemasonry in Croatia (Oxford 1978). See also the chapter by Ambrus Miskolczy in this volume. 
celebrations, or eulogies, that consistently followed in the wake of Kazinczy's published articles of greater or lesser import. ${ }^{53}$ The implicit political programme of these journals also appears consistent on a number of points, such as the specific reinterpretation of the originally medieval office and role of the palatine in the Hungarian state organisation, which was an important topic in the pages of both the Ephemerides and Orpheus. ${ }^{54}$ Interestingly, Croatian issues and news from those territories are given emphasis in the Ephemerides, and behind such information we may perhaps find the Masonic relationships of the Croatian-based Draskovich observance. I think we may risk the hypothesis that the preference for the Latin language in the Ephemerides was not, or was not exclusively, an editorial decision but can be interpreted as part of a cultural concept represented by the Draskovich observance.

The history of eighteenth-century Latin-language journalism currently under review therefore partly supports and partly complements Burke's and Waquet's claim that the Latin language in eighteenth-century Europe is "a language in search of community," which, at the same time, also functions as an element of community identity and a community symbol. How does the present study support this claim?

On the one hand, it can be seen that major changes were taking place within Latin's two main language communities in this period. Although the hegemony of the Catholic Church with respect to the use of Latin, as highlighted by Burke, is unquestionable, it is significant that the only Latin-language journal with a religious affiliation in contemporary Hungary was connected to the Lutheran Church, thus an examination of Protestantism should not be neglected. In the scholarly community of the Republic of Letters, the use of Latin, according to the testimony of journalism, is still intensive but increasingly being suppressed. The examination of Latin journalism suggests a possible reason for this: by the end of the eighteenth century, the system of specialist sciences had emerged in European culture. At the same time, this system was becoming more and more sharply distinguished from the popularisation of sciences, which targeted non-professional audiences and which was becoming increasingly dominant. The latter was justifiably, from the point of view of the sociology of readership, realised in vernacular languages, while Latin was restricted to the arcane

53 A detailed laudation on Kazinczy's career: $E B$ (28 Jan. 1791), 68; further reviews: $E B$ (20 Dec. 1792), 614; (28 Jan. 1791), 66-67; (27 July 1790), 318; (1 Feb. 1791), 75-76; (28 Jan. 1791), 65-66; (23 Aug. 1791), 121.

54 For more details on the subject see P. Balogh, Mozaikok, 26-29 and P. Balogh, "Orpheus sive philosophia-Kazinczy folyóirata Bacon felől olvasva” [Kazinczy's journal read from Bacon's perspective], Sic Itur Ad Astra 61 (2010), 173-188. 
world of professional scholars. The next step in the process took place in the nineteenth century, when the specialised sciences somehow had to prove their social usefulness by aligning themselves with popular trends. Native models of the specialist sciences therefore emerge, naturally at the expense of the Latin language. Thirdly, our analysis of Latin-language journalism has also indicated that the use of Latin language in government offices and jurisdiction can be attributed not only to the survival of a historical tradition, especially in the multilingual and multinational Habsburg Empire. In the eighteenth century, the official and political use of Latin is often linked to the self-identification of emerging and competing social groups. Latin played a symbolic role in the identity of such groups, which cannot necessarily be described as "an 'imagined community' that was international in scope." ${ }^{55}$ In Hungary, the use of the Latin language acquired a symbolic role in noble/feudal community consciousness, in the Hungarus identity of the non-Hungarian-speaking bourgeoisie, in the creation of a Habsburg imperial community awareness, as well as in other, smaller communities, such as the Masonic Draskovich observance. Although the last of these was an international organisation, the use of Latin was intended to support its autonomy and independence. However, the example of the Ephemerides Budenses also demonstrates that, by the end of the eighteenth century, such forms of community identity were becoming increasingly marginalised in contrast to the emerging ethnicity-based national consciousness, which at the same time called for the dominance of native languages at the expense of Latin. The decline of Latin did not therefore signify a loss within the language user communities, but rather resulted from a transformation in the composition and self-ideology of those communities.

55 See fn. 4 . 